\title{
Experience of Application Semicokes Lignite as Barrier Materials in the Production of Primary Aluminium Cells
}

\author{
Alexander V. Proshkin*, \\ Vitaliy V. Pingin and Ivan A. Yarosh \\ «RUSAL ETC»LLC \\ 37/1 Pogranichnikov, Krasnoyarsk, 660111, Russia
}

Received 26.03.2016, received in revised form 31.05.2016, accepted 12.07.2016

Seams of traditional insulating and refractory materials, reduce gas-density of a laying and are places of receipt of aggressive liquid and gaseous components in heat-insulating part of cells cathodes. It causes growth of thermal losses and reduces cells service life. Unshaped material materials which are in a disperse state are considerably deprived of such shortcomings. High efficiency at their production and application caused expansion of scales of their application. However need of careful selection of particle size distribution and strong consolidation of dry barrier mixes, possibility of their division according to fractions in the course of installation increases their cost and imposes certain restrictions on their use. In work results of laboratory, theoretical and industrial researches new unshaped materials with use of products of pyrolysis of coals of the Kansk and Achinsk pool which advantage in relation to the traditional unshaped materials is good physical and working properties and low cost are presented.

Keywords: aluminium production, dry barrier mix, sodium, cell, unshaped material, insulation, refractory.

Citation: Proshkin A.V., Pingin V.V., Yarosh I.A. Experience of application semicokes lignite as barrier materials in the production of primary aluminium cells, J. Sib. Fed. Univ. Eng. technol., 2016, 9(5), 770-781. DOI: 10.17516/1999-494X-20169-5-770-781.

\footnotetext{
(C) Siberian Federal University. All rights reserved

* Corresponding author E-mail address: Aleksandr.Proshkin@rusal.com
} 


\title{
Опыт применения полукоксов лигнитов
}

\author{
как барьерных материалов
}

в алюминиевых электролизерах

\section{производства первичного алюминия}

\author{
А.В. Прошкин, В.В. Пингин, И.А. Ярош \\ ООО «РУСАЛ ИТЦ» \\ Россия, 660121, Красноярск, Пограничников, 37 /1
}

\begin{abstract}
Швы традиционных теплоизоляциионных и огнеупорных материалов снижают газоплотность кладки и являются местом проникновения газообразных и жидких компонентов $в$ теплоизоляциионню часть электролизеров. Это приводит к росту тепловых потерь и сокращчению срока службы электролизеров. Неформованные материаль, находящиеся в дисперсном состоянии, в значительной мере лишены таких недостатков. Высокая производительность при их изготовлении и применении служит причиной расширения масштабов их применения. Однако необходимость тщцательного подбора распределения частиц по размерам и сильного уплотнения сухих барьерных смесей, возможность их расфракционирования при их инсталляции увеличивают их стоимость и ограничивают применение. B работе представлень результаты лабораторных, теоретических и промышленных испытаний нового неформованного материала с использованием продукта пиролизаканско-ачинскихуглей, которыйимеетпреимуществапоотношениюктрадиционным материалам - хорочие физические и рабочие свойства и невысокую стоимость.
\end{abstract}

Ключевые слова: сухая барьерная смесь, натрий, электролизер, неформованный материал, теплоизоляция, огнеупор.

\section{Введение}

Традиционно при монтаже электролизеров производства первичного алюминия применяются огнеупорные и теплоизоляционные изделия в виде кирпичей различных размеров [1]. Недостатками таких материалов и технологий их применения как огнеупоров являются низкая герметичность кладки из-за межкирпичных швов, достаточно высокая стоимость и высокие трудозатраты. Неформованные огнеупорные материалы различного гранулометрического и минералогического составов, находящиеся в дисперсном состоянии, в значительной мере лишены таких недостатков [2-4]. По отношению к формованным изделиям технология изготовления таких материалов требует в 2-3 раза меньше площадей производственных помещений, характеризуется более высокой производительностью (в 4-5 раз) и меньшими (в 5-6 раз) энергозатратами [5]. В настоящее время известно о применении в электролизерах производства алюминия нескольких типов неформованных материалов: глинозем [1], смеси алюмосиликатного [2], оливинового составов [6] и сланцев [7]. Технология использования неформованных материалов (НФМ) при монтаже катодных устройств электролизеров выгодно отличается от технологии с применением кирпичной кладки сокращенным временем монтажа футеровочных материалов и меньшими трудозатратами [8]. В случае применения в качестве неформованного материала глинозема появляется возможность его последующей переработки в электролизеpax или повторного использования в качестве футеровочных материалов, что сокращает ко-

$$
-771-
$$


личество отходов [4]. Однако глинозем уязвим по отношению к проникающим компонентам фторсолей, которые вызывают увеличение его объема и разрушение катодных устройств [1]. Результаты испытаний других неформованных барьерных материалов на основе оливина показали снижение срока службы, что вызвало сомнение в целесообразности их использования в качестве барьерных материалов [5]. В то же время успешное использование преимущественно алюмосиликатных НФМ подтверждается данными мировой практики [2]. Так, средний срок службы китайских электролизеров на 300 кА, монтаж которых был проведен с использованием сухих барьерных смесей (СБС), составлял 2200 сут.

Цель данного исследования - поиск новых неформованных барьерных материалов и оценка возможности применения порошкообразных углеродных материалов для создания барьерных футеровочных материалов в электролизерах производства первичного алюминия на основе результатов лабораторных и промышленных испытаний.

\section{Материалы и методы}

Исследуемыми материалами являлись мелкодисперсный (менее 100 мкм) полукокс бурого березовского угля (ПБУ) марки АБГ-П, производства ЗАО «Карбоника-Ф», г. Красноярск, полученный автотермической неполной газификацией угля с использованием эффекта «обратной тепловой волны», и серийно выпускаемый Магнитогорским огнеупорным заводом шамотный порошок ПШ-1. Были исследованы смеси указанных материалов для организации барьера, препятствующего проникновению агрессивных компонентов в теплоизоляционную часть цоколя.

Эти материалы подвергали испытаниям на химическую стойкость как по отношению к натрию отдельно, так и по отношению совместного действия алюминия, натрия и электролита. Последнее было оценено как криолитоустойчивость и осуществлялось по методике A. Tabereaux [9] на установке, описанной в [10]. Для определения динамики поглощения натрия буроугольным полукоксом была использована методика воздействия паров натрия на образец полукокса бурого угля в герметичном контейнере. Взвешенные на аналитических весах запаянные стеклянные ампулы с металлическим натрием (ТУ 48-05-23-70) помещали в контейнер. Туда же загружали известное количество кокса (до 1 г), закрывали крышкой с одной стороны и герметично сваривали. Свободный конец трубки присоединяли к вакуумной системе течеискателя ПТИ-7А, с помощью которого эвакуировали воздух из рабочей камеры до давления 0,1-10 Па. Затем при непрерывной откачке свободный конец трубки, присоединенный к вакуумной системе, герметично заваривали, и камеру отделяли от вакуумной системы. Сдавливая стенки трубки, ломали ампулы с натрием, не нарушая герметичности камеры. Пробирка помещалась в электрическую двухсекционную печь, где были расположены две термопары для определения температурного градиента в области контейнера с исследуемым образцом и расплавленным металлом. При достижении равновесия между жидкой и паровой фазами, установлении температуры давление достигало определенной заранее рассчитанной величины. Измерения изменения веса исследуемых образцов проводили выгрузкой веществ из прибора и взвешиванием на аналитических весах фирмы Sartotius Research.

Вещественный состав ПБУ исследовали с применением рентгенофазового анализа (РФА), рентгеноспектрального анализа (РСА), комплексного термического анализа (ДТА). Съемка 
дифрактограмм осуществлялась на автоматизированном рентгеновском дифрактометре фирмы Shimadzu XRD-6000 (излучение $\mathrm{CuK \alpha}$ ). Расшифровка шла с помощью информационнопоисковой системы рентгенофазовой идентификации материалов (ИПС ФИ). В связи с отсутствием стандартов для количественного анализа фазового состава (КРФА) использовался метод корундовых чисел (RIR ИПC). Съемка рентгеновских спектров при проведении PCA осуществлялась на автоматизированном волновом рентгенофлуоресцентном спектрометре фирмы Shimadzu XRF-1800. Для полуколичественного рентгеноспектрального анализа применялся метод фундаментальных параметров. Содержание цианидов определялось по методике ПНД Ф 16.1:2:2.2:2.3:3.70-10 с применением фотометрического метода с пиридином и барбитуровой кислотой.

Для измерения коэффициентов теплопроводности порошкообразных материалов и расплавленного электролита был использован метод стационарного теплового режима. Прибор состоял из тигля с исследуемым порошком, который помещали в стальную герметически закрываемую пробирку. Пробирка нагревалась в печи с трехсекционным нагревателем, напряжение на обмотках которого поддерживалась регуляторами ВРТ-3. Фиксируемый тепловой поток в экспериментальной установке задавали нагревателем постоянной мощности (2,9-3,1 ВТ), расположенным во внутреннем цилиндре. Силу постоянного тока в нем регулировали источником питания 55-21. Разность температур между поверхностями внутреннего и внешнего цилиндров в исследуемом материале измеряли образцовыми платина-платинародиевыми термопарами, помещенными в никелевые чехлы, с потенциометром Р 348 с точностью до 0,1 мкВ. Контроль за изотермичностью в зоне нагрева цилиндров осуществляли с помощью дифференциальной хромель-алюмелевой термопары с цифровым вольтметром Щ 68000 с точностью до 0,001 мВ $(\sim 0,03 \mathrm{~K})$.

Проведены расчетно-теоретические исследования теплового состояния промышленного катодного устройства при применении разработанных барьерных материалов с использованием программа ANSYS, а также термодинамический анализ процессов, протекающих в них, с использованием программы HSC 5.1. Проверка свойств нового неформованного материала в реальных условиях эксплуатации (непосредственно под подовыми блоками) проведена на опытном электролизере C-175. Работоспособность оценивалась по технико-экономическим показателям и периодически измеряемым по 15 точкам температурам днища и трех закладных термопар типа XА. Окончательное заключение проводилось на основе результатов аутопсии опытного электролизёра, отработавшего более 2300 сут.

\section{Результаты}

После проведенных исследований на химическую стойкость по отношению к натрию установлено, что при насыщении буроугольного полукокса парами натрия в течение 24 ч его содержание в углеродной решетке буроугольного полукокса составляло всего 0,0774 \%.

Тесты на криолитоустойчивость полукоксов бурых углей в течение 24 ч показали, что при общей высоте 26,7 мм нижняя часть высотой 18-19 мм практически сохранила свои свойства и после разрезания тигля свободно из него высыпалась. Сильная пропитка наблюдалась только на глубине 2-3 мм (рис. 1). Остальная часть образца слабо пропитана парами электролита и натрия. При этом местами присутствовал желтый налет карбида алюминия. Рентге-

$$
-773-
$$


нофазный анализ выявил, что в слабопропитанном материале углерод сохранил свою аморфную структуру, а в сильнопропитанном материале превратился в графит. Глубина пропитки материала 2,4-4 мм при таком эксперименте является достаточно хорошим результатом для барьерных материалов. Испытанный комбинированный материал по стойкости к совместному воздействию электролита и алюминия, безусловно, можно отнести к одному из лучших материалов.

Однако наличие азота в порах полукокса бурого угля при их расположении непосредственно под подовыми блоками при температурах выше 500-600 ${ }^{\circ} \mathrm{C}$ обуславливают высокую вероятность образования цианида натрия:

$$
2 \mathrm{Na}_{\text {пар }}+2 \mathrm{C}+\mathrm{N} 2=2 \mathrm{NaCN}, \Delta \mathrm{G}_{\mathrm{o}} 1223 \mathrm{~K}=-101270 \text { Дж. }
$$

Как показывают результаты термодинамического анализа, наличие шамота должно сдерживать образование цианида натрия (рис. 2), поскольку вначале натрий, поступающий в смесь полукокса и шамота, будет вступать в реакции с образованием альбита и нефелина. И только

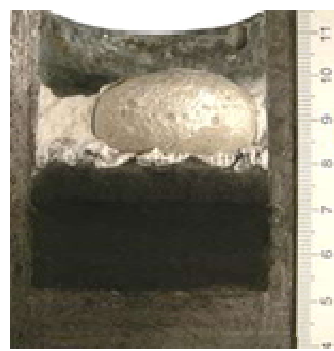

a

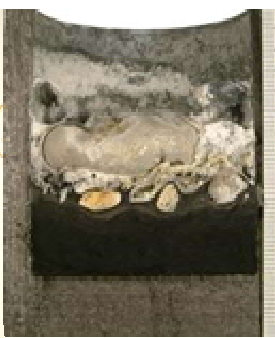

6

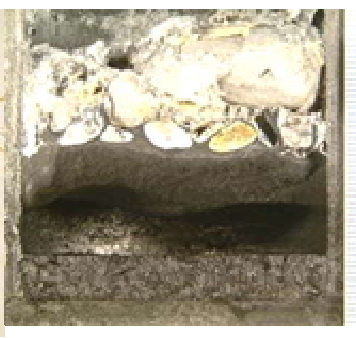

B

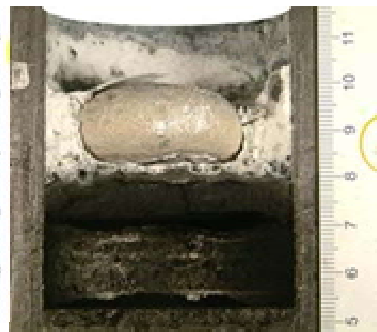

$\Gamma$

Рис. 1. Фотографии образцов буроугольного кокса, выдержанных в контакте с криолит-глиноземным расплавом и алюминием при $1223 \mathrm{~K}, 20$ ч: а - АБГ (уплотненный, 0,76 г $\left./ \mathrm{cm}^{3}\right) ; 6-$ АБГ (неуплотненный,

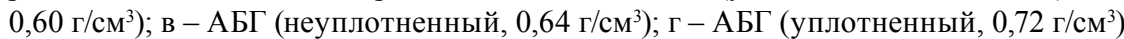

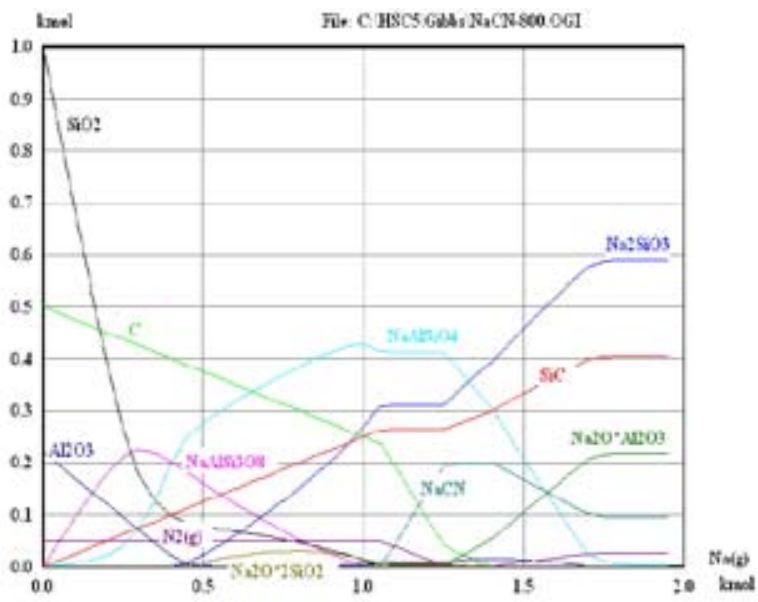

Рис. 2. Термодинамическая диаграмма воздействия паров натрия на смесь полукокса бурого угля и шамота при наличии азота $\left(800^{\circ} \mathrm{C}\right)$ 


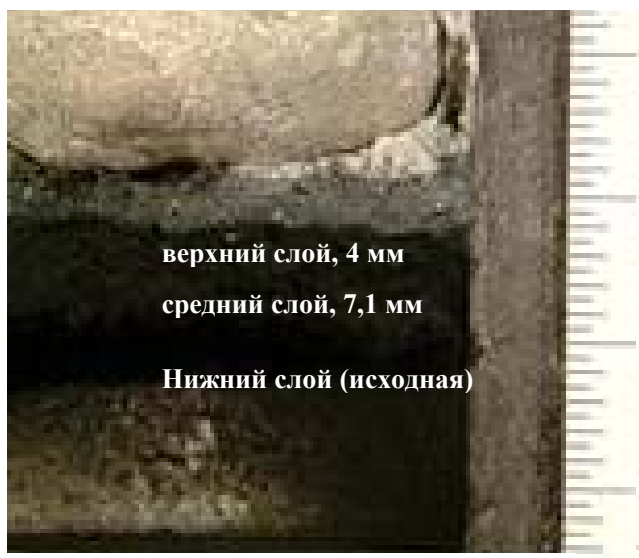

Рис. 3. Вид образца из смеси полукокса бурого угля и шамота после 20 -часовых испытаний на криолитоустойчивость

на заключительном этапе, сопровождающемся распадом нефелина с образованием алюмината натрия, будет формироваться цианистый натрий.

Испытания на криолитоустойчивость барьерной смеси, состоящей из $12 \%$ полукокса и 88 \% шамотного порошка ПШ-1, установили (рис. 3), что в ней, как и в образце из полукокса, имеются три характерные зоны. Верхний слой (4 мм) приобрел светлый цвет и превратился в прочный монолит. Под верхней зоной располагался промежуточный слой - зона слабой пропитки материала толщиной 7,1 мм, внешне слабо отличающегося от исходной смеси, но пропитанного некоторым количеством фторсолей. Нижняя зона толщиной 14 мм практически не подверглась взаимодействию и после разрезания тигля легко высыпалась из него. В ходе эксперимента высота исследуемого материала не изменилась.

Методом рентгенофазового анализа определен вещественный состав вышеуказанных зон. Результаты КРФА, пересчитанные на элементный состав, хорошо совпали с данными химического анализа. Среднее содержание натрия в верхнем слое составило 15,1% (рис. 4).

Образование фаз нефелина замедляло процессы деструкции и графитизации углерода. Углерод находился в форме графита, содержание которого составляло 5,4 \% из-за разбавления пробы криолитом. Следует отметить также наличие значительного количества корунда, образовавшегося, вероятно, в результате химической реакции. В этом слое отсутствуют характерные линии альбита. Образец из средней части (рис. 5) более чем наполовину состоял из нефелина и сопутствующего ему альбита. Вероятно, в процессе образования нефелина участвовал корунд из верхнего реакционного слоя (рис. 4). Наблюдалось большое содержание муллита (26,8 \%). Следует отметить, что хотя металлического кремния и не обнаружено, но фаза $\mathrm{FeSi}$ присутствовала. Содержание натрия составило 5,4 \%.

Образец из нижней части мало трансформирован и близок по химическому составу к исходному материалу, представленному муллитом, кристобалитом и кварцем. Содержание муллита находилось на уровне 70 \% масс. Содержание кристобалита, вероятно, близко к исходному, а малые количества нефелина и альбита обнаружены в результате протечки этих соединений из верхнего слоя. Следует отметить наличие фазы $\mathrm{Al}_{0.7} \mathrm{Fe}_{3} \mathrm{Si}_{0.3}$, образованной вместо $\mathrm{FeSi}$, ве- 
$\mathrm{C}=23,8 ; 0,53 ; 30-1144 ; 5 S$ 115; Na5 Al3 F14; Chiolite, syn; Sodium Aluminum Fluoride:

$\mathrm{C}=22,1 ; 0,21 ; 25-772 ; 5 S$ 49; Na3 Al F6; Cryolite, syn; Sodium Aluminum Fluoride; $\mathrm{R}=$

$\mathrm{C}=28,4 ; 0,55$; 46-1212;S5 0; Al2 03; Corundum, syn; Aluminum 0xide; $\mathrm{R}=63 ; \mathrm{H}=3916$

$C=5,84 ; 0,26 ; 12-212 ; B B$ 230; C; Graphite; Carbon; $R=58 ; H=2973 ; I=1130$

$\mathrm{C}=1$,27; 0,1; 88-2301;CC 404; Ca F2; Fluorite, syn; ; $\mathrm{R}=24 ; \mathrm{H}=3184 ; \mathrm{I}=439$

$\mathrm{C}=3,31 ; 0,15 ; 74-2309 ; \mathrm{CC} 234 ; \mathrm{Si} \mathrm{C} \mathrm{N} ; 2 ; \mathrm{R}=54 ; \mathrm{H}=3970 ; \mathrm{I}=649$

$\mathrm{C}=1,61 ; 0,147 ; 27-1402 ; \mathrm{SS}$ 470; Si; Silicon, syn; Silicon; $\mathrm{R}=64 ; \mathrm{H}=5205 ; \mathrm{I}=638$

C=3,74; 0,21; 47-1881;SI 290; [ Na, K , Ca ]8 ( Si , Al )12 024 ( 5 04 ]2; HałPluyne;

C=0,87; 0,014; 83-2372;CC 83; Na6.65 Al6.24 Si9.76 032; Nepheline [Na-exchanged]

$\mathrm{C}=0,90 ; 0,091 ; 86-793 ; \mathrm{CC} 518 ; \mathrm{Fe}$ Si; ; $\mathrm{R}=50 ; \mathrm{H}=0 ; \mathrm{I}=397$

$\mathrm{C}=7,48 ; 0,123 ; 84-1651 ; \mathrm{CC}$ 85; $\mathrm{Na} 2 \mathrm{Ca} 3 \mathrm{Al} 2 \mathrm{~F} 14 ; ; \mathrm{R}=18 ; \mathrm{H}=5951 ; \mathrm{I}=534$

$\mathrm{C}=0,51 ; 0,010$; 15- 776;SI 0; Al6 Si2 013; Mullite, syn; Aluminum Silicate; $\mathrm{H}=3753$; I=

$\begin{array}{llllllllll}0 & \mathrm{~N} & \mathrm{C} & \mathrm{S} & \mathrm{Si} & \mathrm{Al} & \mathrm{Na} & \mathrm{F} & \mathrm{Ca} & \mathrm{Fe}\end{array}$

$15,7 \% 0,85 \% 6,58 \% 0,21 \% 5,07 \% 23,2 \% 14,6 \% 30,4 \% 2,50 \% 0,60 \%$

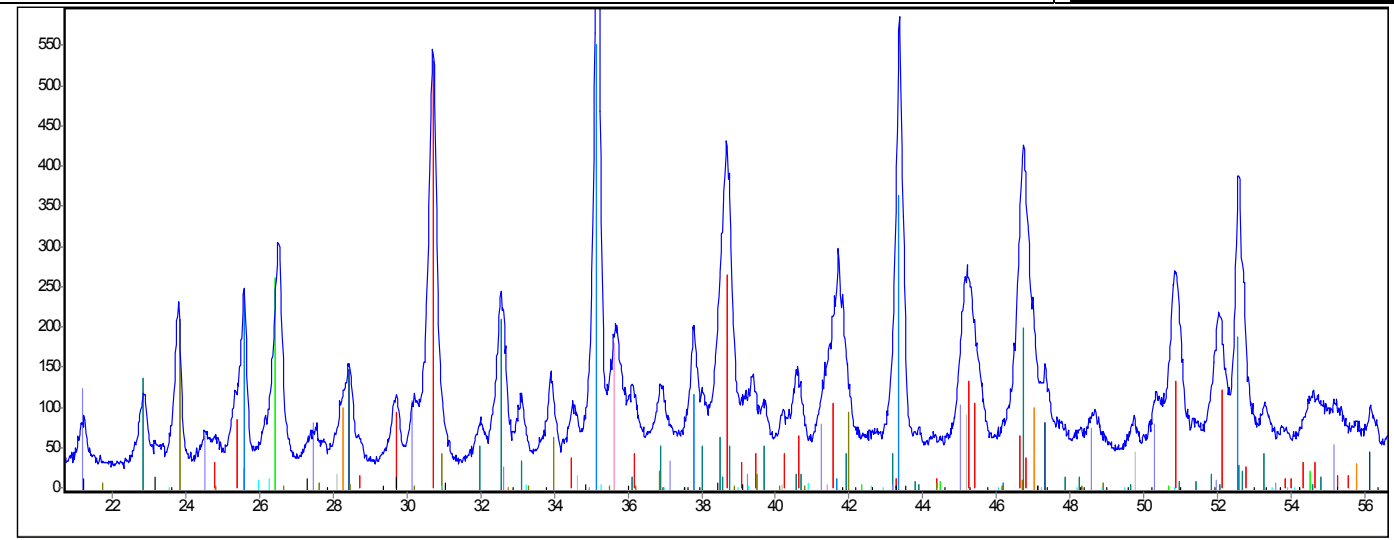

Рис. 4. Результаты РФА и химического анализа верхнего реакционного слоя толщиной 4 мм образца ПШ-1, допированного 12 \% масс. АБГ, выдержанного в контакте с криолит-глиноземным расплавом и алюминием при 1223 К 20 ч

роятно, из-за уменьшения скорости реакции образования металлического $\mathrm{Si}$. Углерод в форме графита не обнаружен. Содержание натрия составляло $0,4 \%$.

Исследование на криолитоустойчивость смесей с различным соотношением порошков буроугольного полукокса и шамота установило, что технически и экономически эффективным вариантом является смесь, содержащая 25-30 \% буроугольного полукокса и 70-75 \% ПШ-1. Как показали сопоставительные испытания на криолитоустойчивость, такой состав комбинированной сухой барьерной смеси (КСБС) обеспечивал самую низкую из известных неформованных материалов степень взаимодействия с компонентами электролита в ходе 20и 40-часовых тестов (рис. 7). Так, по сравнению с традиционно применяемой СБС Е-50 (КНР) глубина проникновения фторсолей в течение времени испытаний в КСБС в два раза ниже. Характерной особенностью этой смеси являлась ее достаточно низкая теплопроводность (рис. 8).

Расчеты теплового состояния катодного устройства промышленного электролизера C-175 показали, что при сохранении вышеуказанных свойств замена традиционно применяемой СБС Е-50 на КСБС приведет к следующим изменениям показателей работы электролизеров:

$$
-776-
$$




\begin{tabular}{|c|c|c|}
\hline $\mathrm{C}=26,8 ; 0,583 ; 15-776 ; 5 I$ 0; Al6 Si2 013; Mullite, syn; Aluminum Silicate;; H=0; I=13 & Химиче & й анализ \\
\hline$C=2,56 ; 0,19 ; 46-1045 ; S S$ 341; Si 02; Quartz, syn; Silicon 0xide; $H=0 ; I=440$ & Элемент & $\%$, масс \\
\hline$C=2,14 ; 0,25 ; 82-512 ; C C$ 535; Si 02; Cristobalite; ;: H=0; I=581 & $\mathrm{O}$ & 38,5 \\
\hline $\mathrm{C}=3,50 ; 0,16 ; 9-466 ; \mathrm{SS} 210 ; \mathrm{Na}$ Al Si3 08; Albite, ordered; Sodium Aluminum Silica & $\mathrm{F}$ & 1,8 \\
\hline C=55.4; 1; 83-2372;CC 83; Na6.65 Al6.24 Si9.76 032; Nepheline, (Na-exchanged); : & $\mathrm{Na}$ & 5,4 \\
\hline 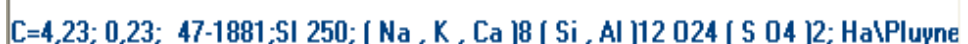 & $\mathrm{Mg}$ & 0,4 \\
\hline 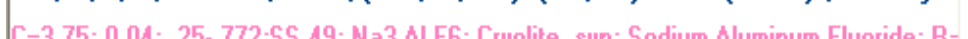 & $\mathrm{Al}$ & 13,1 \\
\hline 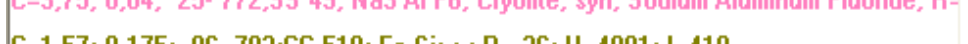 & $\mathrm{Si}$ & 13,3 \\
\hline $\mathrm{C}=1,57 ; 0,175 ; 86-792 ; \mathrm{CC} 510 ;$ Fe Si; $;: R=26 ; H=4981 ; \mathrm{I}=410$ & $\mathrm{~S}$ & 0,03 \\
\hline $\begin{array}{lllllll}0 & \mathrm{~S} & \mathrm{Si} & \mathrm{Al} & \mathrm{Na} & \mathrm{F} & \mathrm{Fe}\end{array}$ & $\mathrm{K}$ & 0,4 \\
\hline $44,9 \% 0,24 \% 22,4 \% 19,4 \% 9,89 \% 2,03 \% 1,05 \%$ & $\mathrm{Ca}$ & 0,5 \\
\hline Углерол в фопме гоафита не обнапужен & $\mathrm{Ti}$ & 0,7 \\
\hline у глерод в форме графита не оонаружен. & $\mathrm{Fe}$ & 1,2 \\
\hline & $\mathrm{C}$ & $\begin{array}{c}\text { не более } \\
10\end{array}$ \\
\hline & $\mathrm{N}$ & 2,8 \\
\hline
\end{tabular}

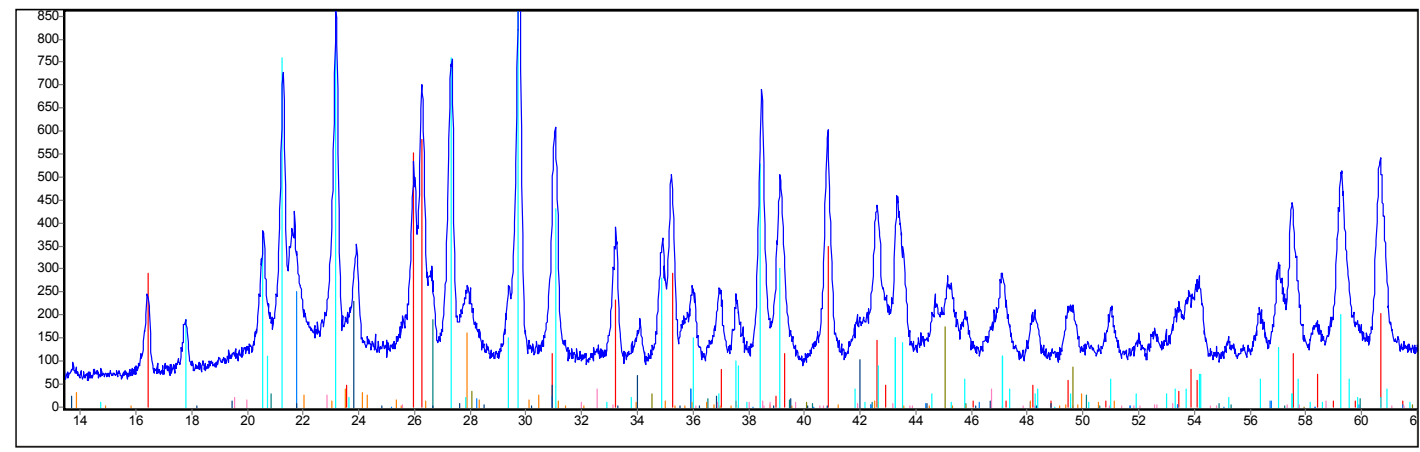

Рис. 5. Результаты РФА и химического анализа среднего пропитанного слоя толщиной 7,1 мм образца ПШ-1, допированного 12 \% масс. АБГ после испытаний на криолитоустойчивость

- температура днища снизится с 85 до $41^{\circ} \mathrm{C}$;

- максимальная толщина гарнисажа уменьшится с 130 до 127 мм;

- длина настыли под анодом сократится с 70 до 25 мм.

\section{Промышленные испытания}

На основе полученных результатов было принято решение о промышленных испытаниях разработанной КСБС в катодном устройстве электролизера С-175. При подготовке опытной смеси для предотвращения пыления в ее состав была введена антипылящая добавка. Уплотнение нового барьерного материала проходило с использованием площадочных вибраторов. Срок службы опытной ванны составил 2310 сут, что свидетельствовало о жизнеспособности новых футеровочных материалов и принятых технических решений. Аутопсия данного электролизера показала, что контакта алюминия с блюмсами не было, не выявлено и проникновение алюминия в цоколь. Причиной останова было появление железа в алюминии из-за контакта алюминия с кожухом в верхней части ванны. Анализ динамики изменения температур днища установил, что полукокс бурого угля почти 2 года препятствовал проникновению натрия и фтористых солей и обеспечивал средние температуры на $15-20^{\circ} \mathrm{C}$ ниже, чем у электролизеров-

$$
-777-
$$




\begin{tabular}{|c|c|c|}
\hline \multirow{2}{*}{$\begin{array}{l}\mathrm{C}=67,5 ; 0,855 ; 15-776 ; \text { SI 0; Al6 Si2 013; Mullite, syn; Aluminum Silicate; } \mathrm{R}=52 ; \mathrm{H}= \\
\mathrm{C}=14,7 ; 1 ; 82-512 ; \mathrm{CC} 535 ; \text { Si 02; Cristobalite; } \mathrm{R}=36 ; \mathrm{H}=2440 ; ; \mathrm{I}=3737\end{array}$} & \multicolumn{2}{|c|}{ Химический анализ } \\
\hline & Элемент & $\%$, масс \\
\hline \multirow{7}{*}{ 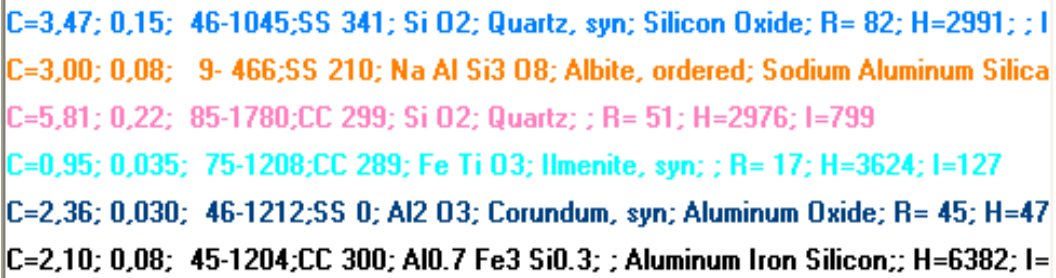 } & $\mathrm{O}$ & 41,1 \\
\hline & $\mathrm{F}$ & 0,9 \\
\hline & $\mathrm{Na}$ & 0,4 \\
\hline & $\mathrm{Mg}$ & 0,4 \\
\hline & $\mathrm{Al}$ & 14,6 \\
\hline & $\mathrm{Si}$ & 15,7 \\
\hline & $\mathrm{S}$ & 0,01 \\
\hline \multirow{6}{*}{$\begin{array}{cccccc}\mathbf{0} & \mathrm{Si} & \mathrm{Al} & \mathrm{Na} & \mathrm{Ti} & \mathrm{Fe} \\
48,6 \% & 21,1 \% & 27,4 \% & 0,26 \% & 0,30 \% & 2,16 \%\end{array}$} & $\mathrm{~K}$ & 0,4 \\
\hline & $\mathrm{Ca}$ & 0,5 \\
\hline & $\mathrm{Ti}$ & 0,8 \\
\hline & $\mathrm{Fe}$ & 1,4 \\
\hline & $\mathrm{C}$ & $\begin{array}{c}\text { не более } \\
12\end{array}$ \\
\hline & $\mathrm{N}$ & 1,9 \\
\hline
\end{tabular}

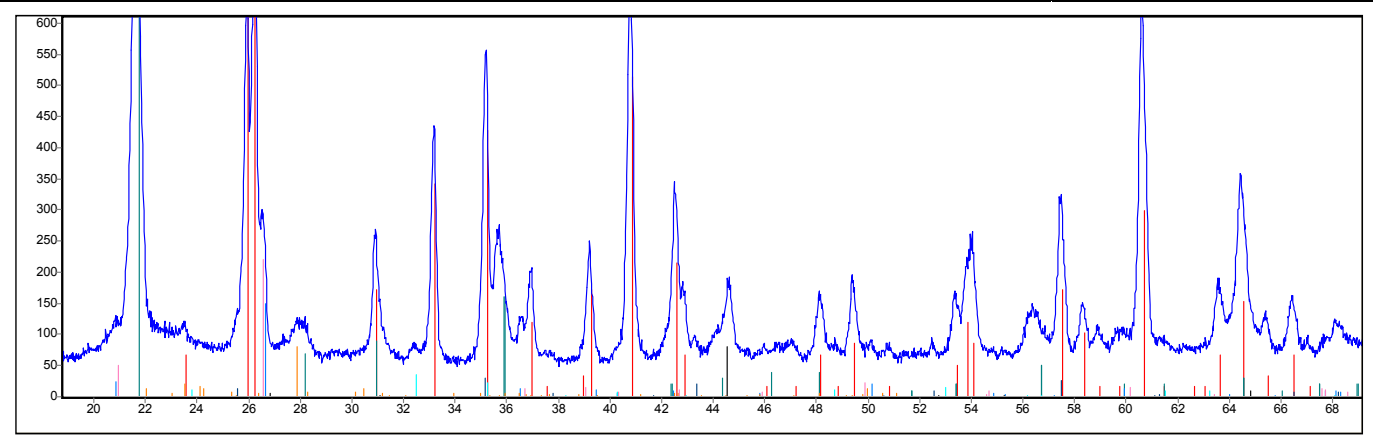

Рис. 6. Результаты РФА и химического анализа нижнего непропитанного слоя толщиной 14 мм образца ПШ-1, допированного 12 \% масс. АБГ, выдержанного в контакте с криолит-глиноземным расплавом и алюминием при 1223 К 20 ч

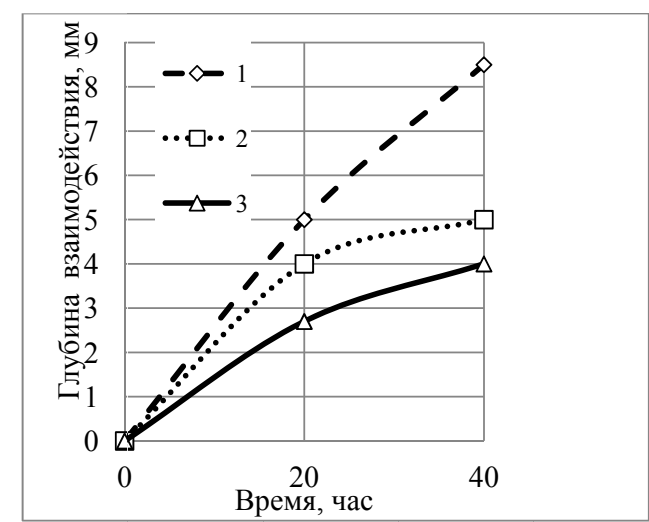

Рис. 7. Зависимость глубины взаимодействия барьерных материалов от времени испытаний: 1 - СБС Е-50; 2 - BorAluBar; 3 - КСБС

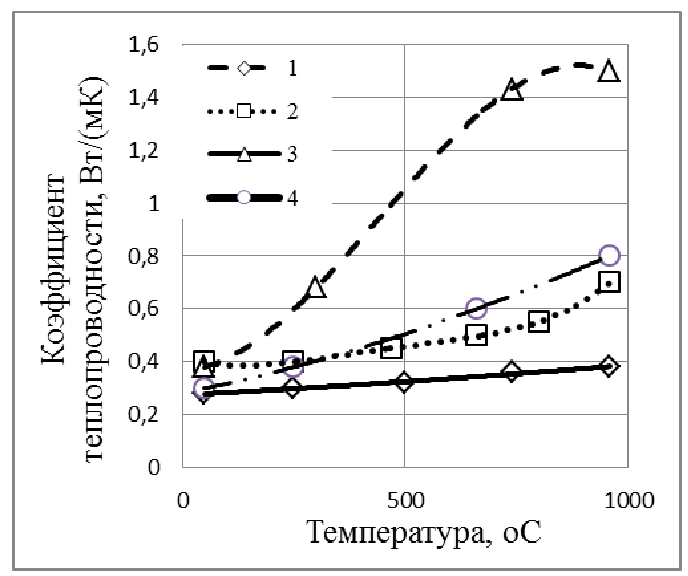

Рис. 8. Коэффициент теплопроводности КСБС (1-3) и ПШ-1(4) при различных температурах и степенях пропитки: 1,4 - исходные; 2 - средняя; 3 - сильная пропитка 


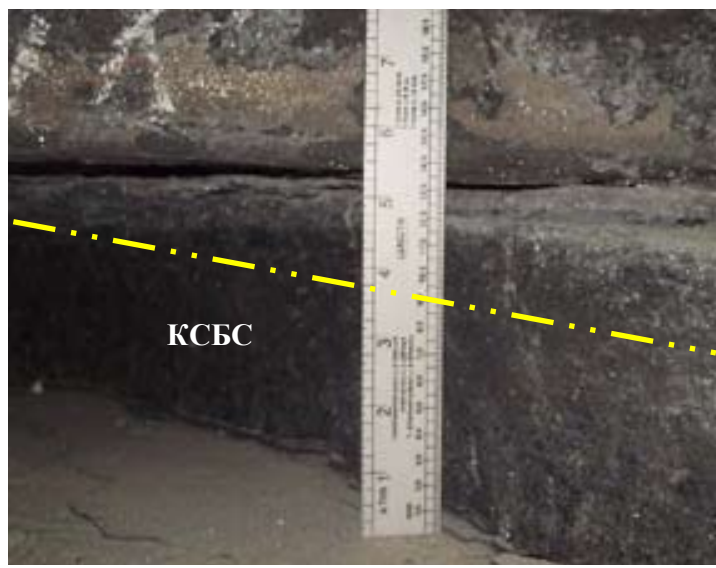

Рис. 9. Состояние КСБС в цоколе катода С-175 спустя 2310 сут службы

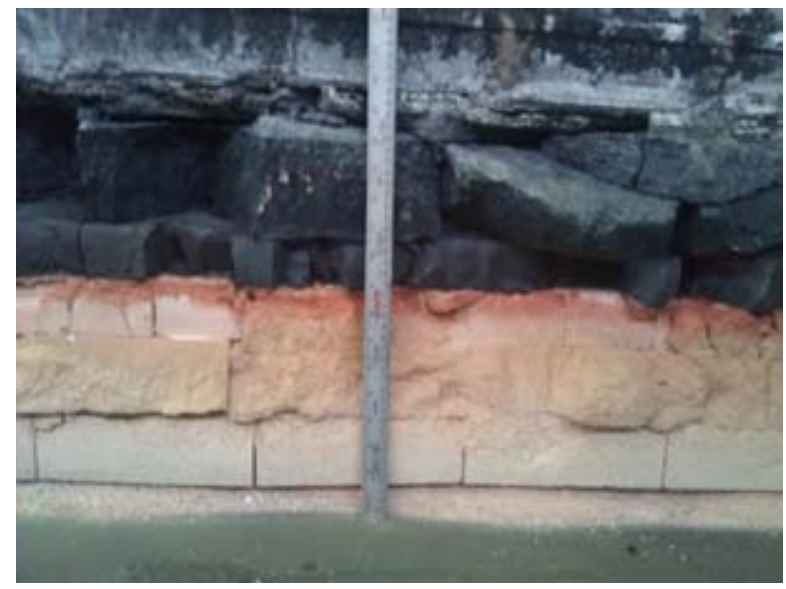

Рис. 10. Состояние футеровочных материалов в цоколе катода С-175 спустя 2310 сут службы

свидетелей. Тем не менее к окончанию службы ПБУ в смеси с шамотом ПШ-1 полностью пропитался фторсолями и барьерный слой увеличился по высоте на 40 мм (рис. 9). Столь незначительное увеличение барьерного слоя обусловило минимальные деформационные изменения катодных стержней. При этом фронт натрия находился на уровне выше третьего слоя кирпичной кладки (рис. 10).

Максимальное содержание цианидов непосредственно под подовыми блоками в испытуемом барьерном материале в центре ванны, находившемся при температурах более $800{ }^{\circ} \mathrm{C}$, составляло $\sim 0,4 \%$, что оказалось ниже обычно фиксируемых значений цианидов в подовых блоках ванн с таким сроком службы.

\section{Обсуждение результатов}

Бурые углей Березовского месторождения имеют значительные балансовые запасы 2453,2 млн т - и высокую эффективность его добычи [11]. Стабильно низкая стоимость как угля ( 350 руб/т), так и получаемого полукокса является одним из его весомых преимуществ. Сопо-

$$
\text { - } 779 \text { - }
$$


ставление величин химической стойкости по отношению к атомарному натрию показало, что буроугольный полукокс адсорбирует атомарного натрия в 4 раза меньше, чем нефтяной кокс, прошедший высокотемпературную тепловую обработку при $2300{ }^{\circ} \mathrm{C}$. Величина поглощения натрия из паров высокотемпературным нефтяным коксом при аналогичных условиях составляет $0,3 \%$, полуграфитом - $1,5 \%$, а газокальцинированным антрацитовым наполнителем, содержащим $30 \%$ графита, -5 \%, [12]. Очевидно, что полукокс бурого угля отличается большим количеством сильных поперечных связей, что препятствует проникновению натрия в материал [13]. Замедление процессов проникновения натрия, в свою очередь, затрудняет смачивание твердой поверхности углерода электролитом и проникновение солевого расплава в поры материала.

Испытания на криолитоустойчивость образцов, содержащих полукокс, показывает резкое уменьшение концентрации натрия при движении от межфазного контакта в глубь углеродношамотного материала и указывает на высокую стойкость и химическую инертность последнего, учитывая особенности его структуры по сравнению с компактными материалами. Однако риск формирования цианидов натрия в высокотемпературных барьерных слоях и длительность реальных процессов вызывают необходимость использования полукоксов бурых углей в смеси с шамотными материалами. Это позволило снизить концентрацию цианида натрия в отработанной КСБС до $0,4 \%$.

\section{Выводы}

1. Разработанный барьерный материал в целом подтвердил свои свойства, однако теплофизические свойства нуждаются в уточнении, поскольку реальные значения температур днища оказались выше расчетных. Промышленные испытания выявили незначительные для такого срока службы толщину линзы и деформацию катодных стержней.

2. Таким образом, срок службы опытного электролизера, его технико-экономические показатели, а также состояние отработанных футеровочных материалов подтверждают возможность использования полукоксов бурых углей как компонентов барьерных материалов в электролизерах производства первичного алюминия.

\section{Работа выполнена при участии Д.А. Бекетова, И.С. Якимова и А.М. Погодаева.}

\section{Список литературы}

[1] Сорлье М., Ойя Х. Катоды алюминиевого электролизера. Красноярск: Версо, 2013, 720 c. [Sorlie M, Oye H. Cathodes in Aluminum Electrolysis. Krasnoyarsk, Verso, 2013, 720 p. (in Russian)].

[2] Sturm E., Prepeneit J., Sahling M. Economic and environmental aspects of an effective diffusion barrier, Light Metals, 2002, 433-437.

[3] Jeltsch R., Cairong C. Dry Barrier Mix in Reduction Cell Cathodes, Light Metals, 2012, 12591263.

[4] Tabereaux A., Mary A., Windfeld M. Evaluation and Performance of powder «Dry-Barrier» refractories for use in Aluminum cell cathodes, Light Metals, 1995, 471-477.

[5] Пивинский Ю.Е. Неформованные огнеупоры, М: Теплоэнергетик, 2003, 488 c. [Pivinskiy Y. Unshaped refractories. M., Teploenergetik, 2003, 488 p. (in Russian)]. 
[6] Siljan O, Slagnes S., Sekkingstad A. and Aaram S. Olivine-based refractories in potlinings of aluminum electrolysis cells, Light Metals. 2004, 405-411.

[7] Соколов В.И., Зуев Н.М. Использование талько-хлоритовых сланцев для футеровки катодного устройства алюминиевых электролизёров, Цветная металлургия, 1995, 9, 21-22. [Sokolov V.I., Zuev N.M. The use of the talc- chloritic shale for the lining of aluminum electrolysis cells, Non-ferrous metallurgy, 1995, 9. 21-22. (in Russian)].

[8] Brandtzeg S., Paulsen K., Siljan O., Thovsen K. Experiences with anorthite powder-based penetration barrier in $125 \mathrm{kA}$ Soderberg cell cathodes, Light Metals,1993, 309-314.

[9] Allaire C., Pelletier R., Siljan O.-J. and Tabereaux A. An improved corrosion test for potlining refractories, Light Metals, 2001, 245-249.

[10] Патрахин И.Ю., Погодаев А.М., Прошкин А.В. и др. Испытания барьерных материалов на криолитоустойчивость: методика и опыт работы, Сборник докладов конференции «Алюминий Сибири - 2005», Красноярск, 2005. C. 331-338. [Patrahin I.U. Pogodaev A.M., Proshkin A.V. and etc. Tests barrier materials cryolite resistance: methodology and experience, Proceedings of the conference «Aluminum of Siberia - 2005», 2005, 331-338. (in Russian)].

[11] Балмасов Н.Н. Минерально-сырьевая база угольной промьшленности России: Т. 2. Регионы и бассейны / Под ред. А. Е. Евтушенко, Ю. Н. Малышева. М.: Издательство Московского государственного горного университета, 1999. 448 c. [Balmasov N., The mineral resources of the Russian coal industry: V. 2. Regions and pools, Eds. A.E. Evtushenko, U.N. Malysheva M.: Publishing house of Moscow state mining University, 1999, 448. (in Russian)].

[12] Oye H. Sodium Expansion of Cathode Materials under Pressure, Light Metals, 1995, 463470.

[13] Рапопорт М.Б. Углеграфитовые межслойные соединения и их значение в металлургии алюминия, М.: ЦНИИцветметинформация, 1967, 67. [Rapoport M., Carbon and graphite interlaminar compounds and value in the aluminum industry, M.: TsNIItsvetmetInformation, 1967, 67. (in Russian)]. 